\title{
Rancang Bangun Bagian Kerangka Mesin Penyerbuk Kunyit dan Pencacah Rosela Sebagai Bahan Dasar Jamu Herbal Kapasitas $5 \mathrm{Kg}$
}

\author{
Ahmad Dony Mutiara Bahtiar'), Fadelis Sukya ${ }^{2)}$, Devina Rosa Hendarti' ${ }^{3)}$, \\ Agustono Heriadi ${ }^{4}$. \\ 1),3)Teknik Mesin, PSDKU Politeknik Negeri Malang Di Kediri \\ ${ }^{2), 4)}$ Menejemen Informatika, PSDKU Politeknik Negeri Malang Di Kediri \\ E-mail: ${ }^{1)}$ Adonbahtiar82@gmail.com
}

\begin{abstract}
Abstrak
Pada perencanaan mekanik pembuatan yang dilakukan pada rangka mesin menggunakan plat besi siku(L) dengan ketebalan $3 \mathrm{~mm}$ dan penggabungan rangka menggunakan sambungan las smaw dengan menggunakan elektroda jenis E 6013. Pada perencanaan perhitungan mekanik pada rangka motor listrik didapatkan hasil gaya total yang bekerja pada rangka sebesar $\mathrm{F}=98 \mathrm{~N}$. dan pada mesin penyerbuk sebesar $F=147 \mathrm{~N}$. dan untuk perakitan komponen mesin menggunakan sambungan baut M8 dan M10.
\end{abstract}

Kata Kunci: Rangka, Pembebanan, Kunyit

\section{Abstract}

In the mechanical planning of the manufacture carried out on the engine frame using an angled iron plate $(L)$ with a thickness of $3 \mathrm{~mm}$ and the incorporation of the frame using a smaw welding connection using an $E 6013$ type electrode. In planning the mechanical calculation on the electric motor frame, the total force acting on the frame is $F=98 \mathrm{~N}$. and in the pollinator $F=147 \mathrm{~N}$. and for the assembly of machine components using $M 8$ and M10 bolted connections.

Keywords: Frame, Loading, Turmeric

\section{PENDAHULUAN}

Pada awal tahun 2020 di Indonesia dikejutkan dengan mewabahnya Covid-19 (corona virus) yang berasal dari Wuhan Cina. Virus ini tidak hanya berdampak pada kesehatan saja akan tetapi juga berdampak pada segala bidang baik ekonomi, social, politik dan budaya. Dalam proses pencegahan Covid-19, pemerintah Indonesia telah melaksanakana program mencucui tangan, memakai masker, dan menjaga jarak yang sering disebut 3M. Program dari pemerintah tersebut tentunya masih kurang berjalan ditandai dengan masih banyaknya masyarakat Indonesia yang 
terjangkit virus corona. Untuk menjaga kondisi tubuh setiap warga negara tentunya dibutuhkan konsumsi makanan dan minuman yang menjaga dan meningkatkan imunitas tubuh. Salah sat minuman herbal yang bisa dikonsumsi oleh manusia adalah jamu herbal. UMKM Dhaha merupakan salah satu UMKM yang ada di Kota Kediri yang memproduksi jamu herbal siap seduh berhan baku dari kunyit dan bunga rosela. Pada proses pembuatan jamu herbal tersebut UMKM tersebut masih menggunakan mesin dan peralatan secara manual.

Salah satu proses produksi yang masih manual adalah proses penyerbukan bahan baku kunyit dan bunga rosela, kunyit dan bunga rosela yang sudah kering dipotongpotong dengan alat sederhana dengan menggunakan gunting dan pisau, setelah kunyit dan bungan rosela dipotong-potong dalam ukuran yang lebih kecil kemudian di blender hingga halus sampai berbentuk serbuk hal tersebut membuat proses produksi jamu herbal membutuhkan waktu yang cukup lama unutuk menghasilkan jamu herbal dalam bentuk serbuk. Berdasarkan hasil wawancara dan pengamatan pada UMKM Dhaha peneliti akan merancang dan membuat mesin penyerbuk kunyit dan Bunga rosela sebagai bahan baku jamu herbal. Berdasarkan uraian diatas, maka diperlukan alat untuk melakukan penyerbuk kunyit dan pencacah bunga rosela yang efektif dan efisien, sehingga dapat membantu meringankan proses produksi serta dapat mengurangi keluhan yang ada, dan berharap dengan adanya perancangan ini UMKM Dhaha Herbal di Jl. Bunga No. 107 RT/RW 15/03 Betik Ngampel Mojoroto Kediri produksi jamu herbal bisa lebih efektif dan efisien. Dalam perancangan mesin ini di bagi menjadi beberapa bagian salah satunya adalah perancangan rangka. Rangka adalah kerangka yang menjadi dasar atau landasan sebuah objek untuk menopang segala beban dari bagian-bagian lainnya seperti body, mesin atau alat elektronik objek tersebut.

Pada chassis ini berpengaruh terhadap kenyamanan dalam meredam getaran atau goncangan berlebihan sehingga gerakan objek tersebut sesuai yang diinginkan. Rancang bangun sendiri adalah merancang atau membuat desain sekaligus mengaplikasikannya ke dalam bentuk nyata sehingga menjadi sebuah hasil karya intelektual [1]. pengambilan judul tersebut berharap bisa bermanfaat baik bagi mahasiswa dan PSDKU Politeknik Negeri Malang di Kota Kediri. Dan pembuatan mesin dapat meningkatkan efisiensi produksi pada UMKM tersebut

Rancang Bangun Bagian Kerangka Mesin Penyerbuk Kunyit Dan Pencacah Rosela Sebagai Bahan Dasar Jamu Herbal Kapasitas 5Kg (Ahmad Dony Mutiara Bahtiar, Fadelis Sukya, Devina Rosa Hendarti, Agustono Heriadi) 


\section{METODE PENELITIAN}

Dalam proses pembuatan rancang bangun rangka pada alat penyerbuk kunyit dan pencacah rosela berkapasitas $5 \mathrm{~kg}$ melalui beberapa tahapan sehingga desain alat dapat selesai dengan baik dan tepat waktu, adapun diagram alir kegiatan sebagai berikut:

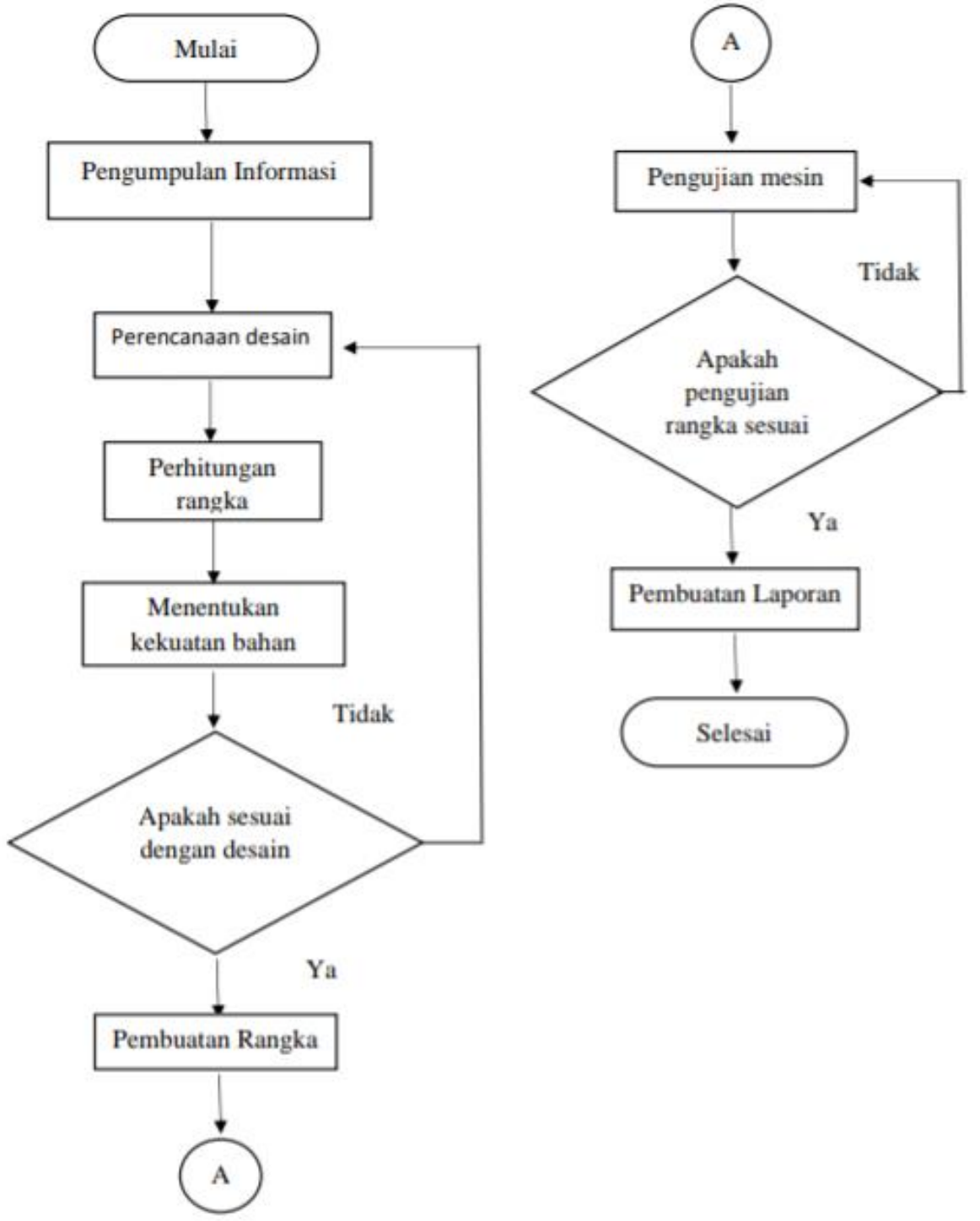

Gambar 1. Diagram Alir Penelitian

\section{HASIL DAN PEMBAHASAN}

Sebelum melakukan pembuatan alat perlu adanya desain awal rancangan untuk mempermudah proses dalam pengerjaan. Dalam perencanaan desain penulis menggunakan software solidwroks, pada perencanaan desain ini terdiri dari rangka gambar desain dapat dilihat dari gambar dibawah ini. 


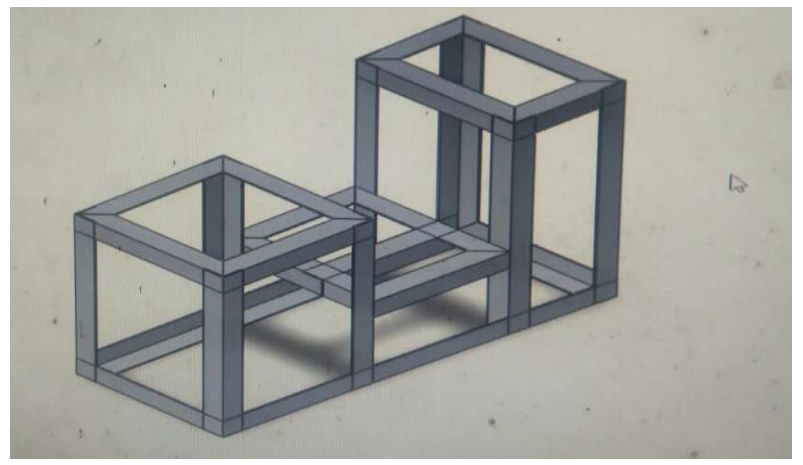

Gambar 2. Desain Rangka

Adapun perhitungan perencanaan mekanik pada rangka sebagai berikut. Pada perncanaan pembuatan mekanik yang dilakukan pada rangka mesin penyerbuk kunyit dan pencacah bunga rosela menggunakan besi L (SIKU) tipe BS 4360 dimensi $40 \mathrm{~mm} \times 40 \mathrm{~mm} \times 3 \mathrm{~mm}$, mesin ini memiliki panjang $760 \mathrm{~mm}$, lebar $200 \mathrm{~mm}$, dan tinggi bagian penyerbuk $500 \mathrm{~mm}$, tinggi bagian pencacah $400 \mathrm{~mm}$ dan tinggi bagian daya penggerak 200mm. penggabungan rangka menggunakan sambungan baut dan mur berukuran M8 dan M17 dan juga menggunakan sambungan las SMAW. Didapatkan bahwa luas penampang besi siku sebesar $16 \mathrm{~cm} 2$ (gaya normal $(\mathrm{N}))$ pada motor listrik sebesar $10 \mathrm{~kg}(10 \mathrm{~kg}$ x 9,8 $\mathrm{m} / \mathrm{s}=98 \mathrm{~N})$. Maka tegangan normal $(\sigma)$ pada rangka motor listrik $61,250 \mathrm{~N} / \mathrm{m} 2$. Tegangan ijin pada rangka sebesar $245 \mathrm{~N} / \mathrm{mm}^{2}$. Jadi karena $\sigma_{i j i n}>\sigma\left(245 \mathrm{~N} / \mathrm{mm}^{2}>61.250\right.$ $\mathrm{N} / \mathrm{mm}^{2}$ ) maka pemilihan bahan rangka dengan ukuran $40 \mathrm{~mm} \times 40 \mathrm{~mm}$ dengan tebal 3 mm diyantakan aman [2] [3] [4].

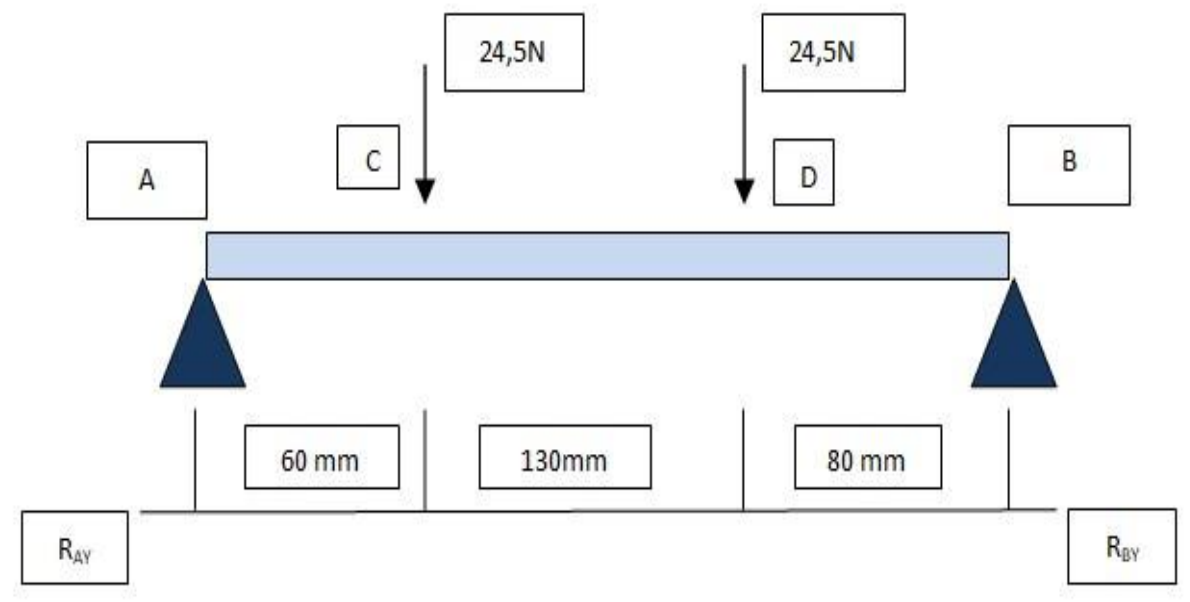

Gambar 3. Pembebanan Pada Motor Listrik

Pada gambar 3.2 dapat dilihat bahwa ada beberapa gaya yang bekerja pada batang yang menopang beban motor listrik, gaya-gaya yang terjadi pada batang: 1.Gaya

Rancang Bangun Bagian Kerangka Mesin Penyerbuk Kunyit Dan Pencacah Rosela Sebagai Bahan Dasar Jamu Herbal Kapasitas 5Kg (Ahmad Dony Mutiara Bahtiar, Fadelis Sukya, Devina Rosa Hendarti, Agustono Heriadi) 
pada titik C atau F1 sebesar 24,5 N. 2.Gaya pada titik D atau F2 sebesar 24,5 N [5].

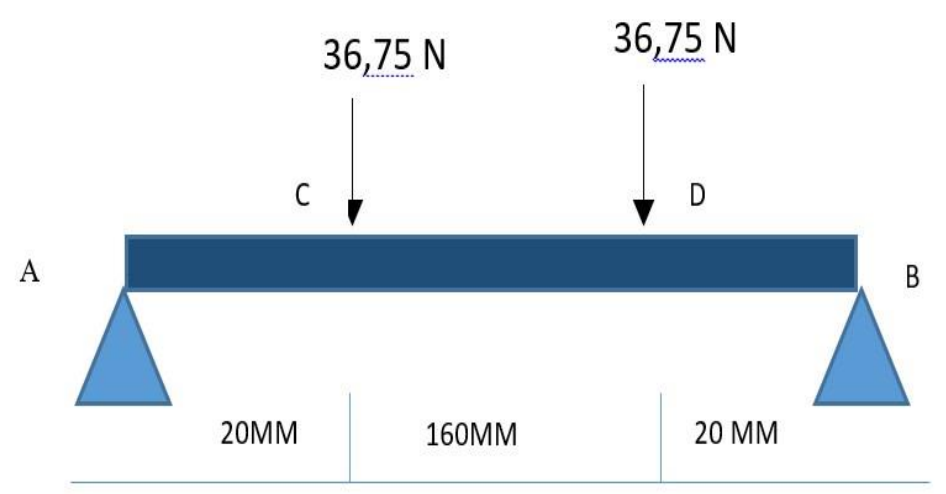

Gambar 4. Pembebanan Pada Penyerbuk Kunyit

Pada gambar 3.3 dapat dilihat bahwa ada beberapa gaya yang bekerja pada batang yang menopang beban penyerbuk. Gaya-gaya yang terjadi pada batang yaitu gaya titil $\mathrm{C}$ atau $\mathrm{F} 1$ sebesar $36,75 \mathrm{~N}$ dan gaya paa titikD atau $\mathrm{F} 2$ sebesar 36,75 $\mathrm{N}$. Berdasarkan gaya diatas dapat diketahui kesetimbangan gaya luar dan kesetimbangan gaya dalam yang terjadi pada batang yang menopang beban penyerbuk kunyit.

\section{KESIMPULAN}

Pada perencanaan mekanik pembuatan yang dilakukan pada rangka mesin menggunakan plat besi siku (L) dengan ketebalan 3mm dan penggabungan rangka menggunakan sambungan las smaw dengan menggunakan elektroda jenis E 6013. Pada perencanaan perhitungan mekanik pada rangka motor listrik didapatkan hasil gaya total yang bekerja pada rangka sebesar $\mathrm{F}=98 \mathrm{~N}$. dan pada mesin penyerbuk sebesar $\mathrm{F}=147 \mathrm{~N}$. dan untuk perakitan komponen mesin menggunakan sambungan baut M8 dan M10.

\section{DAFTAR PUSTAKA}

[1] F. Faujiyah and N. Sidik, "PERANCANGAN RANGKA MESIN PENCACAH CIPUK (ACI KERUPUK)," Jurnal TEDC, vol. 14, no. 1, pp. 29-34, 2020.

[2] H. Wiryosumarto, Teknik Pengelasan Logam, Jakarta: Pradnya Paramita, 1991. 
[3] A. P. Irawan, Diktat Elemen Mesin, Jakarta: Universitas Tarumanegara, 2009.

[4] M. Bagas, "Rancang Bangun Alat Press Hidrolik Kapasitas 5 ton," Universitas Tidar, Magelang, 2020.

[5] F. A. Beer, Statika, Jakarta: Erlangga, 1989. 